\title{
Exchangeable Sodium and Aldosterone Secretion in Children with Congenital Adrenal Hyperplasia due to 21-Hydroxylase Deficiency
}

\author{
B. Loras, F. HaOUr and J.Bertrand ${ }^{[34]}$ \\ I.N.S.E.R.M., Unité de Recherches Endocriniennes et Métaboliques chez l'Enfant, \\ Hôpital Debro usse, Lyon, France
}

Extract

Aldosterone secretion rates (ASR) and exchangeable body sodium $\left(\mathrm{Na}_{\mathrm{e}}\right)$ have been measured simultaneously in 25 cases of congenital adrenal hyperplasia (CAH) with and without salt loss, both during normal and during low salt intake. The degree of 21-hydroxylase deficiency was assessed from the cortisol secretion rate (CSR) and urinary excretion of pregnanetriol and 11-ketopregnanetriol.

In cases with salt loss, the sodium equilibrium was unstable, even with optimum treatment and increased dietary salt intake. Clinical evidence of salt-losing crisis appeared when $15-25 \%$ of $\mathrm{Na}_{\mathrm{e}}$ was lost. In these subjects, a parallel decrease in ASR and CSR usually occurred. The ASR were somewhat elevated in the nonsalt-losing form.

\section{Speculation}

A salt-excreting factor is probably present in CAH, even in the nonsalt-losing form, since the ASR is raised, while the $\mathrm{Na}_{\mathrm{e}}$ remains normal.

Salt loss due to 21-hydroxylase deficiency decreases with age. This appears to be due to modifications in the distribution of body sodium and to an absolute increase in the dietary salt intake rather than to modifications in adrenal secretion.

\section{Introduction}

About one-third of all cases of congenital adrenal hyperplasia (CAH) due to 21-hydroxylase deficiency present with a salt-losing syndrome [32]. This may become evident by day 7-day 12 of life in the most severe form of the disorder, may occur at a later age, or, in some cases, may only arise during a situation of stress.

Although it has been shown in the salt-losing form of CAH that the secretion of aldosterone is deficient, there has been less investigation of concomitant changes in body sodium content. The present study was undertaken in the hope of delineating the interrelation between aldosterone production and disordered sodium balance. Sodium levels in plasma and sodium excretion in urine, as well as the values for exchangeable sodium, have been measured in different situations, namely, during normal dietary sodium intake, and during the administration of a low salt regime.

The exchangeable sodium $\left(\mathrm{Na}_{\mathrm{e}}\right)$ represents the stock of sodium within the organism that can readily be mobilized to maintain electrolytic homeostasis. In the adult, about $30 \%$ of the total body sodium is fixed within the integral structure of bone and is not available for this purpose. In the child, however, almost all the body sodium is exchangeable [17]. The $\mathrm{Na}_{e}$ value in the adult remains fairly constant at about 
$40 \mathrm{mEq} / \mathrm{kg}$ body weight [2]. The value is higher in the child, particularly in the young child. Values obtained for $\mathrm{Na}_{e}$ in healthy newborn infants are of the order of $80-90 \mathrm{mEq} / \mathrm{kg}$ body weight, but by 6 months of age a rapid fall has occurred and the values range from 55 to $65 \mathrm{mEq} / \mathrm{kg}$. Thereafter, the $\mathrm{Na}_{e}$ values in healthy children show a much more gradual fall until they reach adult levels, at about age 12 or $13[11,12,18,26]$ (table I).

Table I. Values for exchangeable sodium in normal subjects related to age ${ }^{1}$

\begin{tabular}{lc}
\hline Age & $\mathrm{Na}_{\mathrm{e}}, \mathrm{mEq} / \mathrm{kg}$ \\
\hline Newborns & $80-90$ \\
6 months & $55-65$ \\
$2-5 \mathrm{yr}$ & $50-60$ \\
$5-10 \mathrm{yr}$ & $45-55$ \\
$12 \mathrm{yr}$ and more & $=40$ \\
\hline
\end{tabular}

1 From references 11, 12, 18, 26.

Ideally, one would wish to measure the $\mathrm{Na}_{e}$ in milliequivalents per kilogram of lean body mass since adipose tissue contains very little sodium. This circumstance sometimes makes it difficult to define the normal limits with precision and it is certainly normal for an obese subject to have an $\mathrm{Na}_{\mathbf{e}}$ value per kilogram total body weight that is less than that of lean subjects.

In most of our cases, in addition to measuring aldosterone secretion, we have also measured cortisol secretion, and the excretion of pregnanetriol in the urine. In this way, it has been possible to assess the degree of enzymatic block and to study the correlation between a deficit in cortisol and aldosterone production and a deficit in body sodium.

\section{Clinical Data and Methodology}

Twenty-five children with congenital adrenal hyperplasia (CAH) due to deficiency of 21-hydroxylase were studied. The ages of the subjects varied from 6 days to 14 years, and the clinical features showed all degrees of severity of the defect. In some cases, the salt loss presented as a crisis; in others, the clinical features did not arouse suspicion in the minds of the parents until the children had reached 3-5 years of age.

The clinical data are summarized in table II. In this table, the degree of salt loss has been estimated on clinical criteria only.

Eight children showing salt loss and two children with the benign form of CAH had been studied prior to the institution of any therapy. In the other children, steroid therapy was stopped for from 3 days to 1 month prior to the investigations. The salt-losing cases were maintained in good general health during this period by appropriate supplementation of their diet with salt.

\section{Sodium}

The sodium content of the diet was calculated from standard tables [27] for the older children and, in the case of the infants, the sodium content of the milk was calculated from the values given by the manufacturer. In a number of cases, these values were verified by direct analysis of the dietary intake.

Sodium levels in plasma and urine were measured by flame photometry.

Tritiated aldosterone $(2-3 \mu \mathrm{Ci})$ and $1 \mu \mathrm{Ci} / \mathrm{kg}$ of ${ }^{24} \mathrm{Na}$ were injected simultaneously. Following $24 \mathrm{~h}$ of equilibration, during which time the urine was collected for measurement of the secretion rate of aldosterone and the excretion of labeled sodium, the specific activity of the plasma sodium and the value for the exchangeable sodium were measured by the isotope dilution method [18].

The exchangeable sodium was calculated by the formula:

$$
\mathrm{Na}_{\mathrm{e}}=\frac{{ }^{24} \mathrm{Na} \text { injected }-{ }^{24} \mathrm{Na} \text { excreted }}{\text { specific activity of plasma }}
$$

where: specific activity $=$

$$
\frac{{ }^{24} \mathrm{Na}(\text { in } \mu \mathrm{Ci}) \text { per } 100 \mathrm{ml} \text { plasma }}{{ }^{23} \mathrm{Na} \text { (in mEq) per } 100 \mathrm{ml} \text { plasma }}
$$

${ }^{23} \mathrm{Na}$ being naturally occurring sodium.

\section{Aldosterone}

The secretion rate of aldosterone was measured by the double isotope derivative assay [24] modified as follows:

a) Aldosterone, liberated by hydrolysis at $\mathrm{pH} 1$, was chromatographed in the E2 B system (isooctane-tertiary butanol-water, 100:50:90) for 20-22 h. If the extract remained pigmented, it was rechromatographed in the Bush 5 system (benzene-methanolwater, 100:50:50) for $7 \mathrm{~h}$.

b) Following acetylation, the diacetate was chromatographed twice in the system cyclohexane-benzenemethanol-water, $4: 4: 4: 1$, and once in the system cyclohexane-dioxan-methanol-water, $4: 4: 2: 1$. The initial chromatography was repeated to secure the removal of excess ${ }^{14} \mathrm{C}$.

c) The oxidation product was chromatographed twice, once in each of the two systems mentioned above.

The purity of the labeled aldosterone that was injected was checked by means of the E2 B system.

WELDON et al. [31] found the ASR to be 72 29.5 $\mu \mathrm{g} / 24 \mathrm{~h}$ for 22 normal subjects whose ages ranged from 8 days to 1 year, the salt intake being normal. In 17 
Table II. Congenital adrenal hyperplasia: clinical data

\begin{tabular}{|c|c|c|c|c|c|}
\hline Case nos. & Age & Sex & $\begin{array}{l}\text { Pseudoherma- } \\
\text { phrodism }\end{array}$ & $\begin{array}{r}\text { Clinical } \\
\text { salt loss }\end{array}$ & Observations \\
\hline & & & Prader & & \\
\hline $1, C S$ & $31 / 12$ yr & F & Type III & 0 & Two affected siblings \\
\hline $2, \mathcal{F C}$ & $5^{4} / 12 \mathrm{yr}$ & M & & 0 & \\
\hline $3, S M$ & $10^{3} / 12 \mathrm{yr}$ & $\mathrm{F}$ & Type IV & 0 & 'Salt-craving' quoted by family \\
\hline $4, \mathcal{F} M C$ & $10^{2} / 12 \mathrm{yr}$ & M & & 0 & Brother of $M C$, case no. 6 \\
\hline $5, P D$ & $12^{2} / 12 \mathrm{yr}$ & F & Type II & 0 & One affected sibling \\
\hline $6, M C$ & $144 / 12 \mathrm{yr}$ & $\mathrm{F}$ & Type II & 0 & Sister of $\mathcal{J} M C$, case no. 4 \\
\hline $7, D C$ & 6 days & $\mathrm{F}$ & Type II & ++ & $\begin{array}{l}\text { First signs of salt loss when } 10 \text { days old; } \\
\text { two affected siblings }\end{array}$ \\
\hline $8, \mathcal{N} L$ & 8 days & $\mathbf{F}$ & Type III & ++ & $\begin{array}{l}\text { First signs of salt loss when } 15 \text { days old; } \\
\text { Sister of } P L \text {, case no. } 12\end{array}$ \\
\hline $9, H C$ & 10 days & $\mathbf{F}$ & Type IV & ++ & First signs of salt loss when 8 days old \\
\hline $10, O M$ & 11 days & $\begin{array}{l}\mathrm{F} \\
\mathrm{M}\end{array}$ & Type III & ++ & $\begin{array}{l}\text { First signs when } 10 \text { days old; } \\
\text { crisis at } 1 \text { month }\end{array}$ \\
\hline $11, S D$ & 18 days & & & ++ & $\begin{array}{l}\text { Breast fed for } 8 \text { days; first signs when } \\
8 \text { days old; crisis at } 15 \text { days }\end{array}$ \\
\hline $12, P L$ & $6 \mathrm{wk}$ & M & & ++ & $\begin{array}{l}\text { Breast fed for } 15 \text { days; first signs when } \\
15 \text { days old; crisis at } 1 \text { month and } \\
3^{6} / 12 \text { during episode of otitis media; } \\
\text { Doca stopped at } 2^{3} / 12\end{array}$ \\
\hline $13, M D$ & 9 wk & $\mathrm{F}$ & Type III & + & Doca stopped at 7 months \\
\hline $14, S F$ & 4 months & M & & ++ & $\begin{array}{l}\text { First signs when } 10 \text { days old; crisis at } \\
3 \text { months during an infectious episode }\end{array}$ \\
\hline $15, P C$ & 4 months & $\mathbf{F}$ & Type III & ++ & $\begin{array}{l}\text { Breast fed for } 2 \text { months; first signs of } \\
\text { salt loss very early; Doca stopped at } 2^{3} / 12\end{array}$ \\
\hline $16, R B$ & 11 months & M & & ++ & $\begin{array}{l}\text { First signs when } 12 \text { days old; crisis at } \\
20 \text { days during episode of otitis media }\end{array}$ \\
\hline $17, D \mathcal{F}$ & $31 / 12$ yr & $\mathrm{F}$ & Type III & ++ & $\begin{array}{l}\text { Crisis at } 1 \text { and } 2 \text { months; crisis at } 36 / 12 \\
\text { during a low salt diet trial; Doca } \\
\text { stopped at } 4^{2} / 12\end{array}$ \\
\hline $18, C F$ & $46 / 12 \mathrm{yr}$ & $\mathrm{F}$ & Type IV & ++ & $\begin{array}{l}\text { First signs when } 8 \text { days old; crisis at } \\
2 \text { months, } 3 \text { months, } 2^{6} / 12 \text { during } \\
\text { infectious episodes; Doca stopped at } 46 / 12\end{array}$ \\
\hline $19, P P$ & $51 / 12 \mathrm{yr}$ & M & & ++ & $\begin{array}{l}\text { Crisis at } 24 / 12 \text { during infectious episode; } \\
\text { Doca stopped at } 4\end{array}$ \\
\hline $20, \mathfrak{J I}$ & $5^{7} / 12 \mathrm{yr}$ & M & & ++ & $\begin{array}{l}\text { Crisis at } 1 \text { month, } 9 \text { months, } 2^{10} / 12 \text {, and } \\
3 \% / 12 \text { without known precipitating factor; } \\
\text { one affected sibling }\end{array}$ \\
\hline $21, A A$ & $6^{11} / 12 \mathrm{yr}$ & $\mathrm{F}$ & Type V & ++ & $\begin{array}{l}\text { Doca stopped at } 3^{9} / 12 ; \text { crisis at } 4^{10} / 12 \\
\text { without known precipitating factor }\end{array}$ \\
\hline $22, M C$ & $79 / 12 \mathrm{yr}$ & $\mathrm{F}$ & Type IV & + & Doca stopped at $6^{10} / 12$ \\
\hline 23, $A G$ & $82 / 12$ yr & $\mathrm{F}$ & Type IV & + & $\begin{array}{l}\text { One affected sibling; first signs of salt } \\
\text { loss when } 1 \text { month old; Doca and salt } \\
\text { stopped at } 4\end{array}$ \\
\hline $24, B B$ & $9 \mathrm{yr}$ & M & & ++ & $\begin{array}{l}\text { First signs at } 1 \text { month; crisis at } 3 \text { and } \\
6 \text { months; Doca stopped at } 7 \\
\text { crisis during a low salt diet trial }\end{array}$ \\
\hline $25, G R$ & $10 \mathrm{yr}$ & $\mathbf{M}$ & & ++ & $\begin{array}{l}\text { First signs when } 15 \text { days old; } \\
\text { crisis during low salt diet }\end{array}$ \\
\hline
\end{tabular}

10 : no clinical evidence of salt loss; $\quad+:$ slight salt loss as witnessed by relatively late presentation of the salt loss, absence of recurrence of salt loss during treatment on the occasion of illness or other stress, a low requirement of deoxycorticosterone acetate (Doca) and of salt supplementation, and tolerance of a low salt regime, either for a few days, or for longer periods with advancing age; $\quad++$ : tendency to severe salt loss. 
normal subjects, in the age range of $1-15$ years, the value was $91 \pm 30.4 \mu \mathrm{g} / 24 \mathrm{~h}$. On a low sodium diet, the mean percentage increase of ASR was $319 \%$ in infants and children. Some of the results contributing to these values were obtained in this laboratory.

\section{Cortisol}

Cortisol secretion rates were determined as follows: Two-to-four microcuries of $1,2{ }^{3} \mathrm{H}$ cortisol were injected and estimates were made on a one-fifth portion of the 24-h urine output from which free steroids had been removed by a chloroform extraction. Glucosiduronate conjugates were hydrolyzed by means of $\beta$ glucuronidase (Ketodase), and the resulting free steroids extracted with chloroform. After washing with $0.1 \mathrm{~N} \mathrm{NaOH}$, the extracts were purified by Florisil column chromatography with collection of the $25 \%$ methanol fraction in chloroform. The fraction was chromatographed on paper in the Bush system (benzene-methanol-water, 100:55:45) for $20 \mathrm{~h}$ and in the E2B system for $8 \mathrm{~h}$. The radioactivity was measured in the three major metabolites THF, allo THF, and THE [33] and quantitative estimation of these compounds was achieved by the PORTER-Silber [19] technique.

In some cases of $\mathrm{CAH}$, THE remained contaminated even at this stage and gave a specific activity which was less than that found with the other two metabolites. In such cases, the secretion rate was calculated from the specific activities of THF and allo THF only.

The mean normal value obtained in this laboratory is $11 \pm 3 \mathrm{mg} / \mathrm{m}^{2} / 24 \mathrm{~h}$ for all ages, save the neonatal period [5]. Under ACTH stimulation (25 mg perfused over $8 \mathrm{~h}$ ) the values rise to $30-40 \mathrm{mg} / \mathrm{m}^{2} / 24 \mathrm{~h}$.

In all cases, when secretion rates were being measured, the total radioactivity in the urine was estimated to verify that there had not been an appreciable loss of urine.

\section{Pregnanetriol and 11-Ketopregnanetriol}

Pregnanetriol and 11-ketopregnanetriol were measured by gas-liquid chromatography (GLC).

Following hydrolysis with $\beta$-glucuronidase, steroids were extracted with toluene and separated by paper chromatography with the system hexane-benzenemethanol-water, 70:30:80:20 for $12 \mathrm{~h}$. Pregnanetriol and 11-ketopregnanetriol were located from reference standards run in parallel and were eluted. The results obtained following GLG were not corrected for losses.

Fig. 3. Aldosterone secretion rates $(\mu \mathrm{g} / 24 \mathrm{~h})$ in normal children and in cases of CAH aged 2-14 years, on normal and low salt $\square$ regimes. Shaded zone, ASR $($ mean $\pm \mathrm{SD})$ for normal subjects aged $1-15$ years on a normal salt intake (31).

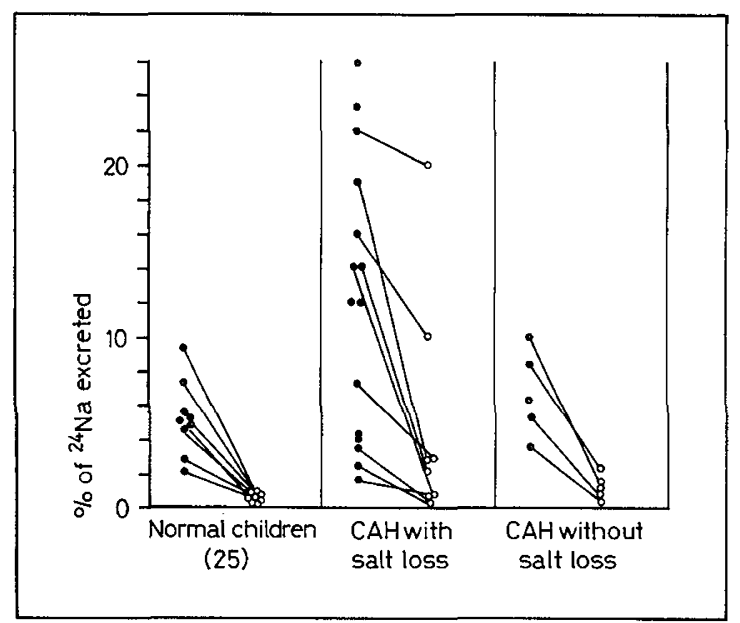

Fig. 1. Percentage of ${ }^{24} \mathrm{Na}$ excreted in the 24-h urine during normal $\bullet$ and low salt $\circ$ regimes.

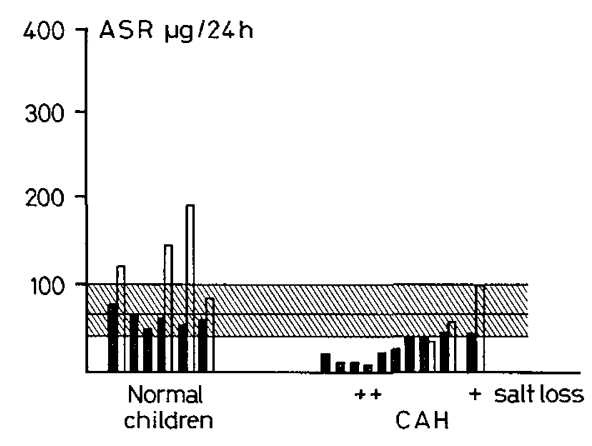

Fig. 2. Aldosterone secretion rates $(\mu \mathrm{g} / 24 \mathrm{~h})$ in normal children and in cases of CAH less than 1 year old, on normal $\square$ and low salt $\square$ regimes. Shaded zone, ASR (mean \pm SD) for normal infants aged 8 days-1 year on a normal salt intake (30).

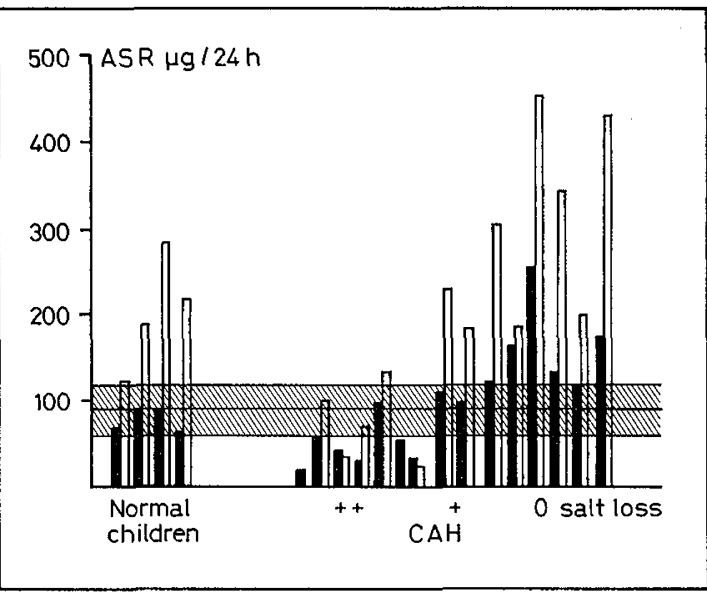


The 17-ketosteroids and the total ketogenic corticoids were measured by the technique of APPLEBY et al. [1] and Few [15].

\section{Results}

Results are given in table III. Abnormalities of sodium balance in $\mathrm{CAH}$ were demonstrated by measurement of the percentage of labeled sodium excreted in the urine of patients (24-h period) (fig. 1). Normal subjects excreted 3-7\% sodium on normal salt intake and less than $1 \%$ when on a low salt intake [26]. Patients with $\mathrm{CAH}$ who had no salt loss responded to a low salt diet by a reduction in their sodium excretion and by a reduction in the percentage of ${ }^{24} \mathrm{Na}$ excreted in the 24-h urines. Salt losers showed a variable excretion of ${ }^{24} \mathrm{Na}$ per $24 \mathrm{~h}$, from 1.8 to $25 \%$. In the majority of these subjects, this value does not decrease during administration of a low sodium diet.

In the salt losers, the sodium levels in plasma were frequently low, even when salt supplements were given (case nos. 10, 11, 15, and 21). Low plasma sodium levels also may be found in the simple form of the disorder, on a low salt regime or on a normal salt intake (case nos. 13, 21, and 22), and lowered plasma sodium may even be found in cases who do not show clinical evidence of salt loss (case nos. 3 and 5).

\section{Exchangeable Sodium}

Patients without salt loss had a $\mathrm{Na}_{\mathrm{e}}$ value that was normal under conditions of normal sodium intake, with little change during administration of a low salt diet. In normal subjects, a reduction of $6-8 \%$ is observed on a low salt regime [26]. These children with CAH on a low salt regime, however, although they do not show salt loss frequently show a loss of weight (case nos. 3, 4, and 6) and a reduction in their plasma sodium levels (case nos. 3, 5, and 6).

In all salt losers under 1 year of age, the $\mathrm{Na}_{e}$ value was below normal whether on normal sodium intake or receiving sodium supplements. A low $\mathrm{Na}_{\mathbf{e}}$ was also found in two older salt losers (case nos. 20 and 24). In the other salt losers, the $\mathrm{Na}_{e}$ values were normal or low normal, but these values were likely to have been influenced because they received salt supplements. Typical salt losers cannot conserve sodium during salt restriction; the exceptions were patients with a mild form of the disorder (case nos. 13 and 22). A clinically evident crisis state of salt losing corresponds to a reduction in the pool of exchangeable sodium of $15-20 \%$.

\section{Aldosterone Secretion Rates (ASR)}

The ASR in salt-losing infants (under 1 year of age) were all low, ranging from 9 to $44 \mu \mathrm{g} / 24 \mathrm{~h}$. Only one infant (case no.13) was able to support a significant reduction in sodium intake; clinically she had a mild form, and was able to double her ASR under a low $\mathrm{Na}$ diet. In two infants, reduction of the salt supplements did not give rise to any significant increase in the ASR and this regimen was poorly tolerated (case nos. 15 and 16). The ASR values before and after the salt reduction were 38 and $36 \mu \mathrm{g} / 24 \mathrm{~h}$ in one case and 44 and $56 \mu \mathrm{g} / 24 \mathrm{~h}$ in the other.

In some of the older salt losers (case nos. 18 and 21), the base-line ASR values (44 and $106 \mu \mathrm{g} / 24 \mathrm{~h}$ ) were normal; however, during salt restriction, their ASR values were frankly subnormal. In other children, the base-line ASR values were low and there was little or no response to the low salt diet (case nos.17, 19, 20, 24, and 25).

Children with $\mathrm{CAH}$ who were not salt losers showed ASR values that were normal or above normal (124$258 \mu \mathrm{g} / 24 \mathrm{~h})$ and invariably responded to a low salt regime (188-455 $\mu \mathrm{g} / 24 \mathrm{~h}$ ) (figs. 2 and 3).

\section{Pregnanetriol and 11-Ketopregnanetriol}

The level of pregnanetriol excreted in the urine was raised in all cases and was further increased following ACTH administration. In the youngest subjects, 11ketopregnanetriol was excreted in greater quantity than pregnanetriol itself. This was noted in only one of the older subjects (case no.25) who remained a severe salt loser.

17-Ketosteroids and total ketogenic corticoids were excreted in considerable amounts by all subjects. In two salt losers in whom treatment had been stopped for only 3 and 5 days, respectively (case nos.23 and 24) at the time of the first estimations, the values were already extremely high and near their maximum. On clinical grounds, however, case no. 23 did not have a severe defect. Almost all the investigations were carried out when the adrenal glands of the patients had returned to what we assumed was their full degree of activity, although, due to the passage of time, this might not necessarily be the degree of activity prior to treatment.

\section{Cortisol Secretion Rates (CSR)}

Children with the salt-losing form of CAH showed cortisol secretion rates that were widely scattered, with values ranging from immeasurably low to subnormal. The response to ACTH was equally variable, being none (case nos.12, 16, and 20), inadequate (case no. 23), or even paradoxical with a lowered CSR following stimulation (case nos. 24 and 25). The correlation between a low cortisol secretion rate and a high degree of salt loss is fairly good.

Cases of CAH without salt loss showed CSR values that were low or normal. They showed a response to ACTH with an increase in cortisol secretion, but this response was invariably less than normal. 


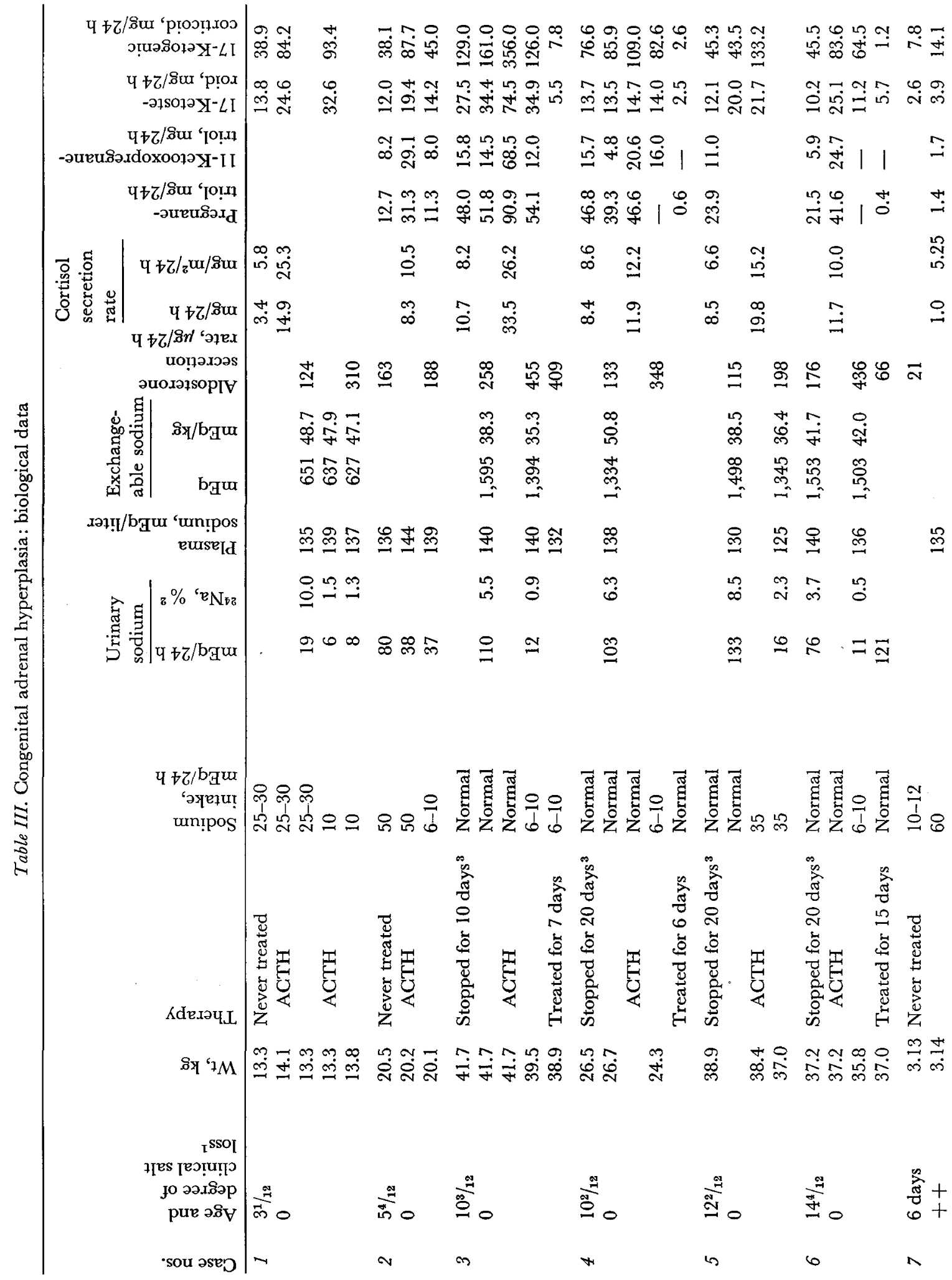




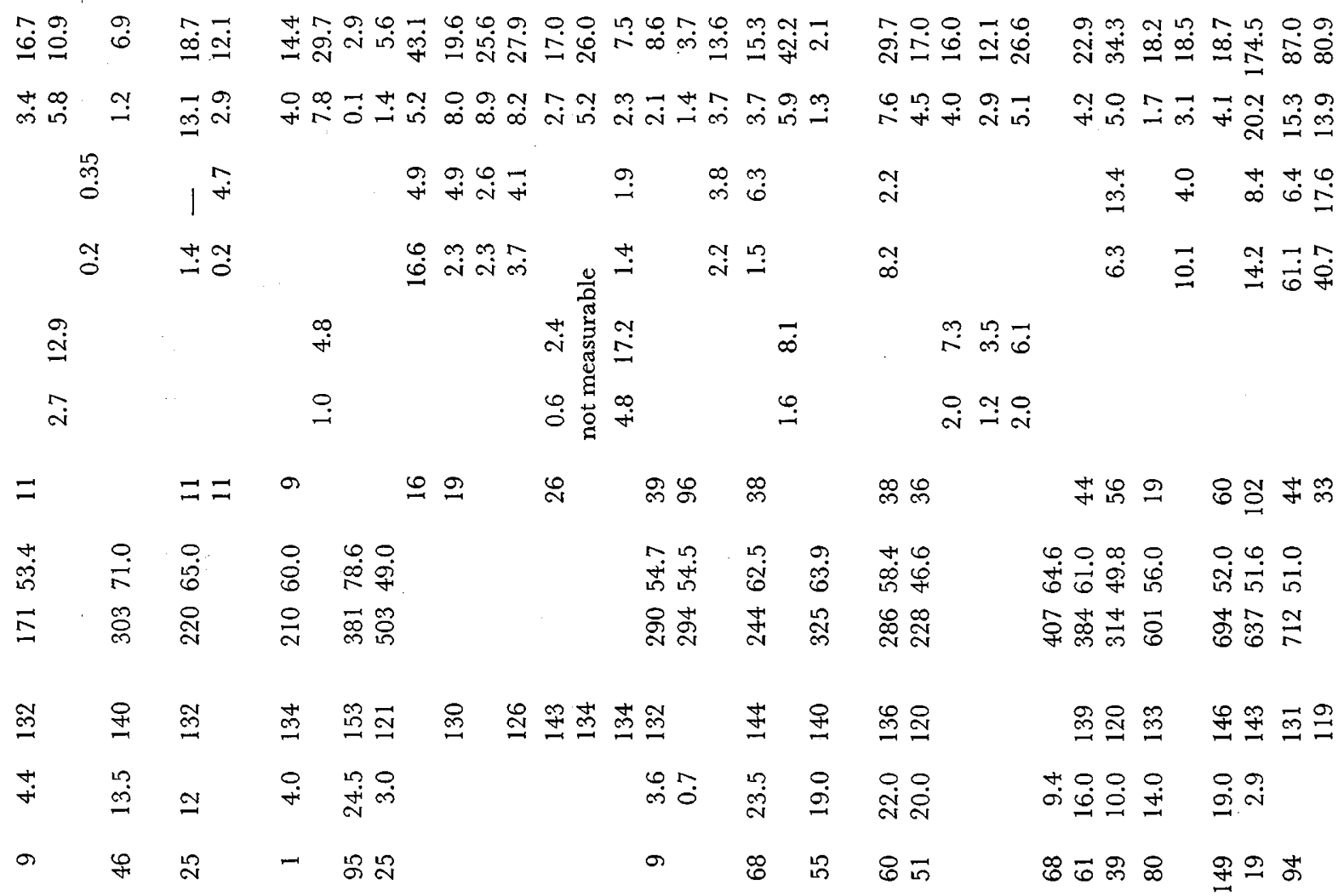

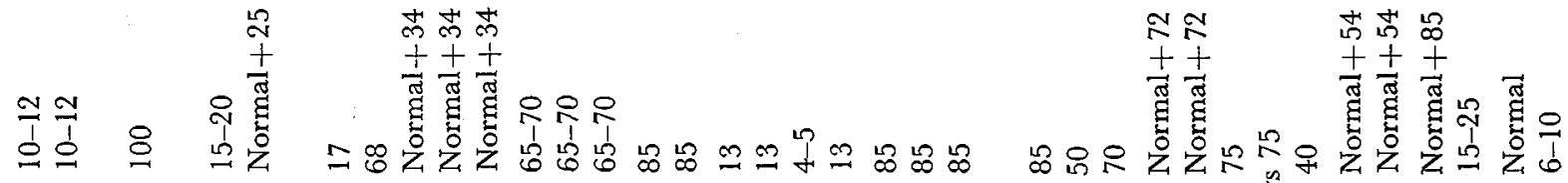

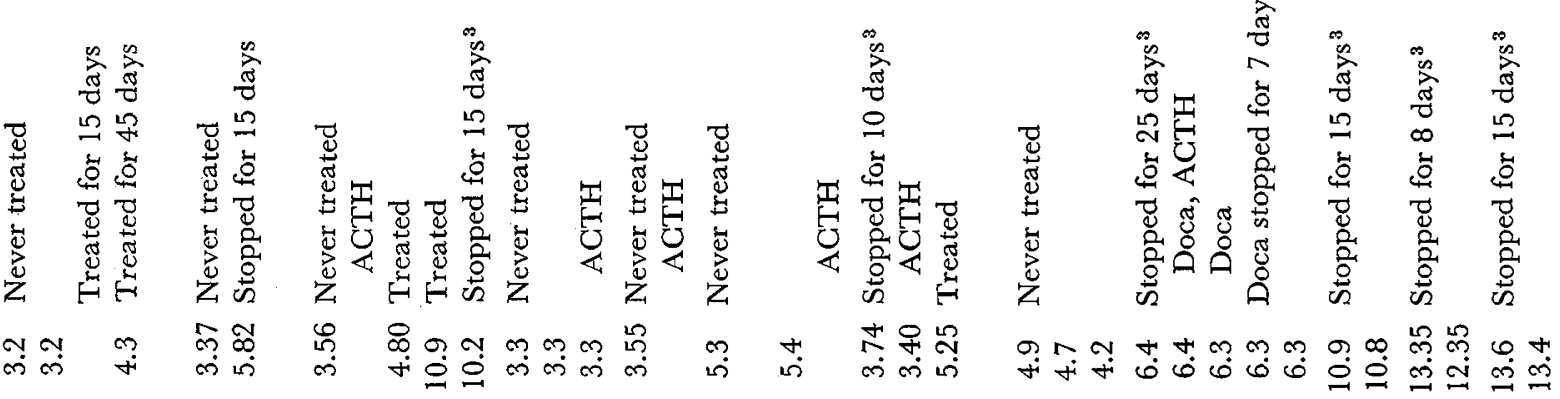

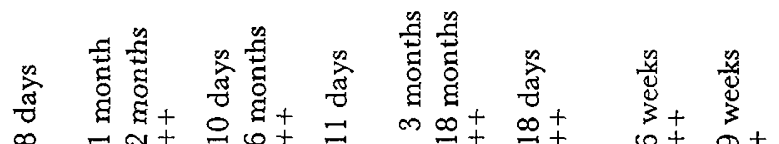

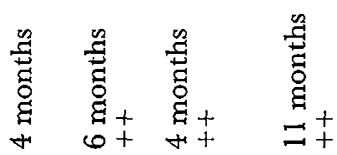
$\frac{a}{m+}+\frac{a}{d+}+\frac{\pi}{n+}+$
$\infty$
a: $:$
$\approx \quad \cong \quad$

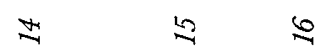
$\therefore \approx 2$ 


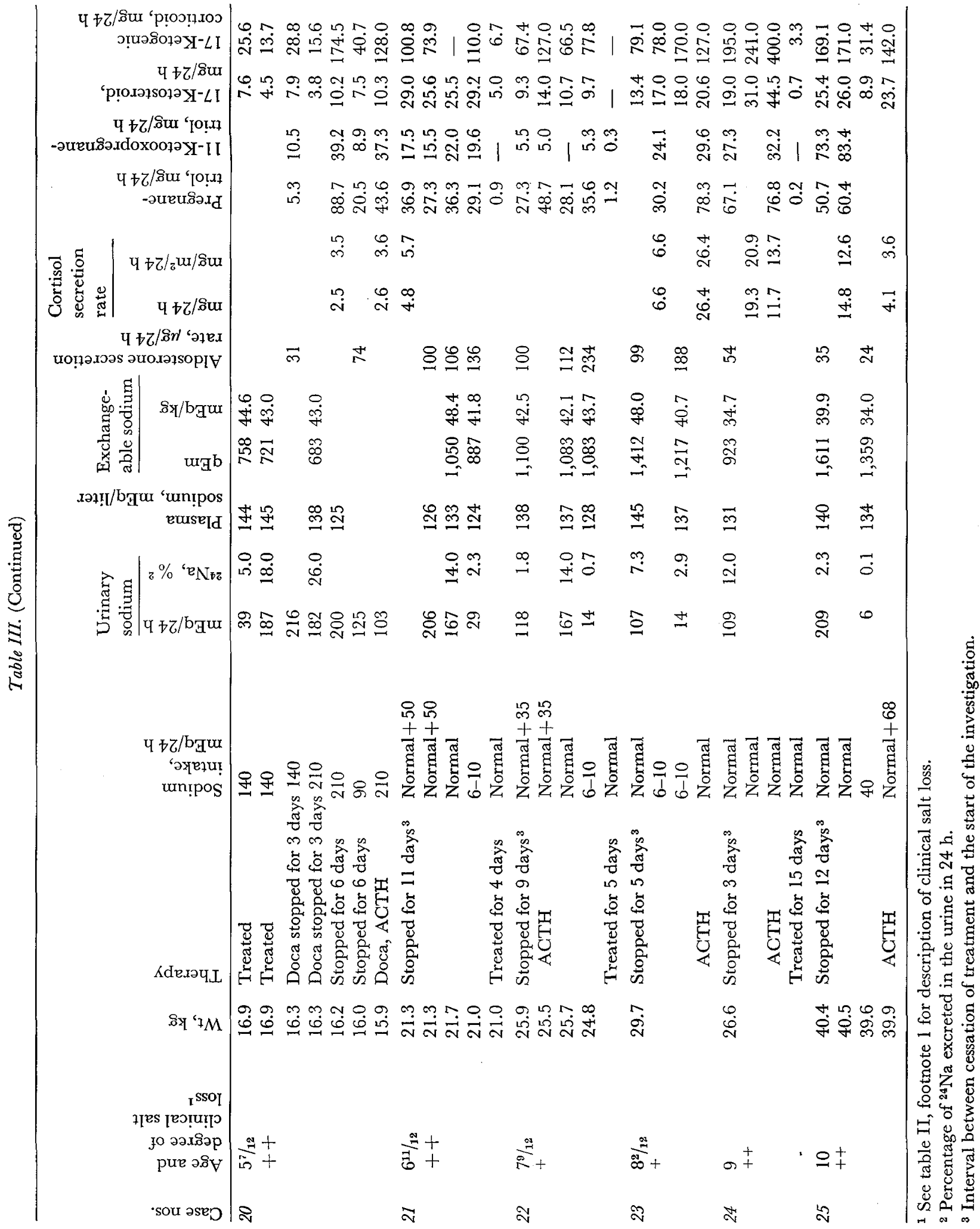




\section{Discussion}

\section{Pregnanetriol and 11-Ketopregnanetriol}

The predominance of 11-ketopregnanetriol over pregnanetriol in infants under 1 year of age $[14,15]$ is probably a manifestation of a more general phenomenon that is also found in the 17-ketosteroids of children with GAH $[16,17]$.

It was of interest to note that this infantile pattern of adrenal secretion persisted in case no. 25 and, to a limited extent, in case no. 20 who showed an increased proportion of 11-ketopregnanetriol during stimulation with ACTH and during salt restriction. It may be significant that these subjects were two of the three children in the series who remained severe salt losers despite the passage of time.

In general, the older patients continued to excrete 11-ketopregnanetriol, but in proportionately smaller amounts. FINKELSTEIN [16] found measurable excretion of 11-ketopregnanetriol in 44 of 50 cases of CAH, and the 6 subjects not excreting this compound probably suffered from the form of CAH due to deficiency of $11 \beta$-hydroxylase. 11-Ketopregnanetriol is not excreted by normal subjects in measurable quantities and would appear to arise only during intense stimulation of the adrenals with ACTH. FinkeLsTeIN found this compound in the urine of patients suffering from Cushing's syndrome associated with adrenal hyperplasia but not in cases of adrenal tumor.

In CAH, it is possible that $11 \beta$-hydroxylase deprived of its normal 21-hydroxylated substrates, acts upon those steroids formed in great quantity, particularly 17-hydroxyprogesterone.

The abnormal excretion of pregnanetriol is reduced rapidly by therapy. Case nos. 4,21 , and 22 show that after only 4-6 days of treatment the urinary levels are low. It is emphasized, however, that in subjects with $\mathrm{CAH}$ under 1 year of age, assay of urinary pregnanetriol alone is inadequate because of the importance of the 11-keto form, and could lead to serious underestimation of the quantity of adrenal precursor compounds secreted.

\section{Sodium}

The four newborns that were studied before clinical evidence indicated salt losing (case nos.7, 8, 9, and 10) showed low sodium levels in plasma, and in the three cases in which it was studied, the $\mathrm{Na}_{\mathrm{e}}$ showed a severe deficit. The negative sodium balance in these infants would, therefore, appear to arise very early and, probably, as suggested by Bongrovanni et al. [8] dates from the time of birth.

Case no. 13 is of interest in that she showed a value for $\mathrm{Na}_{\mathrm{e}}$ that was less than normal during normal salt intake despite a capacity for further aldosterone pro- duction, demonstrable on restricting salt. Although the $\mathrm{Na}_{\mathrm{e}}$ was below normal and the plasma sodium was on the low side, the clinical condition at the time was satisfactory and the excretion of sodium in the urine was less than the dietary intake.

In the newborns (case nos.8, 9, and 10), and in the other subjects during salt restriction (case nos. 15, 16, 21 , and 25), clinical signs of salt loss appeared. In all of these cases, the loss of sodium reached or surpassed $15-20 \%$ of the $\mathrm{Na}_{\mathrm{e}}$ value of the child in optimum condition. Salt loss in the urine is indicated by the insuffi-

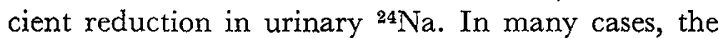
institution of a low salt diet led to increased excretion of total ketogenic corticoid (case nos. 16, 18, 21, 22, and 23 ), and the increased excretion of pregnanetriol itself was indicated in case no.22. Thus, a low salt intake, even though it does not lead to a clinically evident saltlosing crisis, may still create a situation of stress for these subjects and provoke an increased secretion of endogenous ACTH. In contrast, in case nos. 20 and 25 in whom the introduction of a low salt regime had led to a frank salt-losing crisis, the steroid excretion was diminished. A probable interpretation of this result is that the adrenals had become exhausted.

In children with the nonsalt-losing form of $\mathrm{CAH}$, in the absence of treatment the $\mathrm{Na}_{\mathrm{e}}$ is seen to be normal for the age and body build, although in case no. 1 the value was rather low. Likewise, the percentage excretion of ${ }^{24} \mathrm{Na}$ was normal for dietary conditions, but these normal values were associated with aldosterone secretion rates that tended to be higher than those of normal children.

During treatment capable of maintaining the salt losers in good general health the $\mathrm{Na}_{\mathrm{e}}$ values were found to be normal (case nos. 8, 10, and 14) or still low (case no. 10). These findings and the great variation in sodium excretion suggest that sodium equilibrium remains rather unstable even during optimum therapeutic conditions.

\section{Factors Involved in Salt Loss}

Three hypotheses have been put forward to explain the presence or absence of salt loss in CAH due to 21hydroxylase deficiency [8]. Firstly, it has been suggested that there may be two adrenal 21-hydroxylases acting on two types of substrates, steroids with an hydroxyl group at C-17, and precursors of aldosterone. In the simple form of the disorder only the first enzyme would be involved, and in the salt-losing form both would be deficient.

Secondly, some authors hold that the limited capacity for aldosterone secretion is in itself sufficient to explain the salt loss and that the degree of deficiency of a single enzyme is responsible for the varying degrees of severity of the syndrome. 
Finally, the presence of a factor promoting salt excretion has been suggested, a factor which is probably found among the precursors of cortisol and which is secreted in considerable quantity as a result of the enzymatic block. This factor is believed to act by competitive inhibition with aldosterone at the level of the renal tubule and not as a primary agent prompting sodium excretion. This theory suggests that some affected children compensate for the tendency to salt loss by increasing their secretion of aldosterone and these are the nonsalt losers. The others, in whom the capacity for aldosterone secretion is limited, cannot overcome the effects of the factor and these cases are, clinically, the salt losers.

The investigations described here do not permit us to differentiate between a one- or a two-enzyme defect. The most that can be said is that, in general, the severity of the defect in cortisol secretion corresponds with that in aldosterone secretion. This does not support the idea of two enzymes or of two separate genes being involved.

Among the factors concerned in salt loss there is no doubt that the limited capacity to secrete aldosterone is important. Our observations support those already reported [10, 14, 21, 25, 29].

The most severely affected salt losers have the lowest CSR. This relation is already known [7] but it does not explain the interrelation between sodium and cortisol. These children also have a very low ASR; thus, although the cortisol insufficiency associated with the salt loss could be a causative factor due to lack of the 'permissive' effect of cortisol [8], and although the presence of a salt-excreting factor in the precursors could play a role, the major factor may well be, quite simply, the inadequate ASR which is a constant association.

There are several arguments in support of the idea of a salt-losing factor. 1) Steroid therapy brings a fall in the aldosterone secretion rate $(3,21,25$, and case nos. 3 and 6).2) A positive relation between the excretion of pregnanetriol in urine and that of aldosterone has been described by HALL and Hokfelt [22] and by MAtтox et al. [28] in both types of CAH. We have found the same relation between ASR and either urinary pregnanetriol or urinary total 17-ketogenic corticoids in nonsalt-losing patients, although the relation has not been defined on a mathematical basis. The existence of this positive relation is strongly in favor of the presence of a salt-losing factor since even if inexact, urinary pregnanetriol is a good index of the quantity of adrenal precursor steroids that have been formed. 3) Cases of CAH without salt loss tend to have elevated ASR values when untreated. The ASR values of our six children can be regarded as on the high side. Above normal values for ASR in nonsalt losers have also been found in two of three cases by JArLER et al. [23], and high values have also been reported by KoWARSKI et al. [25] and by BARTTER et al. [3].

The evidence of an elevated ASR in the absence of steroid therapy suggests that a salt-losing factor is present but is compensated. An explanation is required, however, for the inconstant nature of this phenomenon. In previous studies [3, 21] a few ASR values were within normal limits or only slightly elevated. The five cases of DEGENHART et al. [14] and the four cases of NEw et al. [29] have ASR values considered normal and one can find neither correlation between these varying values for aldosterone secretion and the 17-ketosteroid values nor correlation between ASR and the other variables as they are presented, namely presence or absence of a treatment period before investigation, sodium intake, chronological age, sex, and age of the child when treatment was first begun. A possible exception would be urinary pregnanetriol values.

GODARD et al. [21] suggested that the capacity to secrete aldosterone is limited, even in the nonsaltlosing subjects. Uurak [30] was of the same opinion in view of his finding of an abnormally high excretion of 11, 18-dihydroxypregnanetriol, and $18 \mathrm{OH}-\mathrm{THA}$ [33], suggesting "that aldosterone deficiency in the saltlosers was a more severe expression of a biosynthetic defect which could occur, in compensated form, in nonsalt-losers as well'. In our cases of nonsalt losers (case nos. 1-6) the ASR response to a low salt regime was certainly not greater than normal (yet the pool of $\mathrm{Na}_{e}$ was reasonably well maintained). It is, therefore, difficult to understand why some cases show only a normal or subnormal rise in ASR with a low salt intake while others [3] show a very striking rise (to $3,244 \mu \mathrm{g} / 24 \mathrm{~h}$ ).

If patients without salt loss can exhibit reasonable satisfactory aldosterone production and $\mathrm{Na}_{e}$ conservation, however, they can also show evidence of some minor abnormality such as loss of weight during a low salt regime or even a lowering of the sodium level in plasma. The institution of a low salt regime can therefore be regarded as a stress situation in the nonsalt losers, as in the salt losers, but of much less severity: This may be explained by a limitation in the capacity to secrete aldosterone as well as by the concept of a salt-losing factor.

These two concepts are in no way in opposition and it seems reasonable to presume the coexistence of two factors-the salt-excreting factor and the insufficiency of both cortisol and aldosterone-their respective importance being inversely proportional and varying according to the gravity of the deficit. An increasing maturity of renal function with age and the dietary sodium intake must also be taken into consideration.

The syndrome of salt loss will appear when there is failure of equilibrium between the production of salt- 
losing factor (illustrated by the ketogenic corticoid levels) and the production of cortisol and aldosterone. The disequilibrium and the salt loss will be worse when the child is very young and the sodium intake is poor.

\section{The 'Recovery'}

The recovery from salt loss, which is known to occur in the majority of cases, can be explained by allied arguments. This 'recovery' usually occurs between 3 and 6 years of age, and in clinical practice means that one may reduce the frequency and later, stop completely, the administration of deoxycorticosterone acetate (Doca) or other mineralocorticoids. Likewise, it is possible to gradually reduce the salt supplementation during the years after mineralocorticoids have been stopped.

The 'recovery' is not perfect. In situations of stress, the needs for Doca and for salt again arise, and, in the absence of stress, a strict low salt intake is poorly tolerated. Our patients (case nos.15, 18, 21, and 22) went into negative sodium balance on a low salt diet and could not conserve $\mathrm{Na}_{\mathrm{e}}$. Nevertheless, the improvement on the state occurring in the early months and years of life was quite spectacular.

The mechanism of the recovery is not known, although newborns are known to have a most unstable water and sodium control.

An alteration in renal function with age, which permits improved conservation of sodium under the influence of equivalent amounts of aldosterone, is very unlikely. Cases of CAH respond well to aldosterone from a very early age [20].

The possibility that the mechanism concerned with secretion of cortisol and aldosterone is improved with age has also been considered but this conjecture is highly unlikely. We have, in fact, repeated measurements of secretion of aldosterone following a considerable time interval to see if there were significant modifications and the results in two cases show that there were not (case nos. 9 and 10).

The one remaining factor that alters with time is the sodium intake and this shows some relation with ASR in normal subjects. Furthermore, the relative as well as the absolute sodium intake increases as the child grows. It would seem, therefore, that Doca can be stopped when the diet contains sufficient salt to balance or to overcompensate for the limited degree of aldosterone production of which the adrenals are capable, and that this dietary sodium is a factor of vital importance in producing the equilibrium.
References and Notes

1. Appleby, J.E.; Gibson, G.; Norymberski, J.K. and StubBs, R.D.: Indirect analysis of corticosteroids. I. The determination of 17 hydroxycorticosteroids. Biochem.J. 60: 453 (1955).

2. Arons, W.A.; Nustmovich, B.; Vanderlinde, R.J. and THORN, G.W.: Effect of exogenous adrenocortical hormones and states of adrenal dysfunction on body sodium and potassium composition. J.clin. Endocrin. 18: 611 (1958).

3. BartTer, F. G. ; Henkin, R.I. and Bryan, G.T.: Aldosterone hypersecretion in 'non salt-losing' congenital adrenal hyperplasia. J. clin. Invest. 47: 1742 (1968).

4. Bergatrand, C. G.; Birke, G. and Plantin, L. O. : Differences in corticosteroid excretion pattern between infants and children with the adrenogenital syndrome. Acta endocrin., Kbh. 34: 508 (1960).

5. Bertrand, J.; Loras, B.; Gilly, R. et CauteNEr, B.: Contribution à l'étude de la sécrétion et du métabolisme du cortisol chez le nouveau-né et le nourrisson de moins de trois mois. Path. Biol. 11: 997 (1963).

6. Bertrand, J.; Roux, H. and Cotre, G.: Paper chromatography of urinary 17 ketosteroids in children. Acta endocrin., Kbh. 45: suppl. 89 (1963).

7. Bonglovanni, A.M. and Eberlein, W.R.: Defective steroidal biogenesis in congenital adrenal hyperplasia. Pediatrics 21: 661 (1958).

8. Bongiovanni, A. M.; Eberlein, W.R.; Goldman, A.S. and NEw, M.: Disorders of adrenal steroids biogenesis. Recent Progr. Hormone Res. 23: 375 (1967).

9. Bongrovanni, A.M.; Eberlein, W.R.; Smith, J.D. and McPaDden, A.J.: The urinary excretion of three G21 methyl corticosteroids in the adrenogenital syndrome. J.clin.Endocrin. 19: 1608 (1959).

10. Bryan, G.T.; Kliman, B. and Bartter, F. C.: Impaired aldosterone production in 'salt-losing' congenital adrenal hyperplasia. J. clin. Invest. 44: 957 (1965).

11. Ghristian, J.R.; Talso, P.J.; Karezeris, M.S.; SPAFFord, N.R.; JaGkson, M. and Larson, M.: Total body water and exchangeable sodium in normal full term newborn infants. Amer.J.Dis. Child. 92: 325 (1956).

12. Corsa, L.; Gribetz, J.R.; Cook, G. and Talbot, N. B.: Total body exchangeable water, sodium and potassium in hospital normal infants and children. Pediatrics 17: 184 (1956).

13. David, R.R.; Bergada, G. and Mrgeon, G.J.: Effect of age on urinary steroid excretion in congenital adrenal hyperplasia. Bull. Johns Hopk. Hosp. 117: 16 (1965). 
14. Degenfyart, H.J.; Visser, H. K. A.; Wilminkand, R. and Groughs, W.: Aldosterone and cortisol secretion rates in infants and children with congenital adrenal hyperplasia suggesting different 21 hydroxylation defects in 'salt-losers' and 'non saltlosers'. Acta endocrin., Kbh. $48: 587$ (1965).

15. FEw, J.D.: A method for the analysis of urinary 17 hydroxycorticosteroids. J. Endocrin. 22: 31 (1961).

16. Finkelstein, M.: Estimation of pregnanetriolone, the estrogens and testosterone as an aid to clinical diagnostic; in: C. CAsSANo: Research on steroids, p. 67 (Il pensiero scientifico, Rome 1964).

17. Forbes, G. B.: in: Comar and BronNer: Mineral metabolism, vol.II, part.B, 2 (Academic Press, London/New York 1962).

18. Forbes, G. B. and Perley, A.M.: Estimation of total body sodium by isotope dilution. I. Studies in young adults. J. clin. Invest. 30: 566 (1951).

19. Gleen, E. M. and Nelson, D. H.: Chemical method for the determination of 17 hydroxycorticoids and 17 ketosteroids in urine following hydrolysis with $\beta$ glycuronidase. J. clin. Endocrin. 13: 911 (1953).

20. GreenberG, A.J.; MaNamara, H. and MaCrorx, W.W.: Renal tubular response to aldosterone in normal infants and children with adrenal disorders. J.clin. Endocrin. 27: 1197 (1967).

21. Godard, G.; Riondel, A.M.; Veyrat, R.; MeGevand, A. and Muller, A.F.: Plasma renin activity and aldosterone secretion in congenital adrenal hyperplasia. Pediatrics 41: 883 (1968).

22. Hall, K. and Hokfelt, B.: Glinical and steroid metabolic studies in four siblings with congenital virilizing adrenal hyperplasia. Acta endocrin., Kbh. 52: 535 (1966).

23. JaIleR, J.W.; Ulick, S. and Lieberman, S. : Aldosterone and hydrocortisone secretion rates in patients with the salt-losing form of congenital adrenal hyperplasia. Trans. Ass. amer. Physicians 72: 149 (1959).

24. Kliman, B. and Peterson, R.E.: Double isotope derivative assay of aldosterone in biological extracts. J. biol. Chem. 235: 1639 (1960).

25. Kowarski, A.; Finkelstein, J.W.; Spaulding, J.S.; Holman, G.H. and Migeon, G.J.: Aldosterone secretion rate in congenital adrenal hyper- plasia. A discussion of the theories on the pathogenesis of the salt-losing form of the syndrome. J. clin. Invest. 44: 1505 (1965).

26. Loras, B.; Haour, F. et Bertrand, J.: Mesure du sodium échangeable et du taux de sécrétion d'aldosterone chez des enfants. G.R.Soc.Biol., Paris 161: 2490 (1967).

27. MaCance, K.A. and Widdowson, E.M: The chemical composition of food. Medical Research Council (Her Majesty's Stationary Office, London 1946).

28. Mattox, V.R.; Hayles, A.B.; Salassa, R.M. and Dion, F.R.: Urinary steroid patterns and loss of salt in congenital adrenal hyperplasia. J.clin. Endocrin. 24: 517 (1964).

29. New, M.I.; Mrller, B. and Peterson, R.E.: Aldosterone excretion in normal children and in children with adrenal hyperplasia. J.clin. Invest. 45: 412 (1966).

30. UlICK, S. : Aldosterone biosynthesis in congenital adrenal hyperplasia. Abstract no.6. 49th Meeting of the Endocrin. Soc., June 1967.

31. Weldon, V.V.; Kowarskx, A. and Migeon, G.J.: Aldosterone secretion rates in normal subjects from infancy to adulthood. Pediatrics 39: 884 (1966).

32. WrLkrns, L.: The diagnosis and treatment of endocrine disorders in childhood and adolescence, p. 340 (Thomas, Springfield, IL 1957).

33. The following abbreviations have been used in this paper: THF: $3 \alpha, 11 \beta, 17 \alpha, 21$-tetrahydroxy-5 $\beta$-pregnane-20-one. allo THF: $3 \alpha, 11 \beta, 17 \alpha$, 21 -tetrahydroxy- $5 \alpha$-pregnane-20-one. THE: $3 \alpha$, $17 \alpha, 21$-trihydroxy-5 $\beta$-pregnane-11, 20-dione. $18 \mathrm{OH}$-THA: $3 \alpha, 18,21$-trihydroxy- $5 \beta$-pregnane11, 20-dione.

34. We thank Professor M.Jeune, Professor P. MonNET, and Professor R. FRANçoIs for allowing us access to their patients; Dr. CLAUde J. Mrgeon for his advice and criticism; and Dr. DAvid M. CATHRO for translating this material. Informed consent was obtained for all subjects in this study.

35. Requests for reprints should be addressed to: J.BERTRAND, M.D., I.N.S.E.R.M., Unité de Recherches Endocriniénnes et Métaboliques chez l'Enfant, Hôpital Debrousse, Lyon 5e, France. 36. Accepted for publication October 3, 1969. 